\title{
Trace elements in Arctic and Antarctic glacier fjords
}

\author{
MARK JAMES HOPWOOD ${ }^{1}$, CASE VAN GENUCHTEN ${ }^{2}$, \\ STEPHAN KRISCH $^{1}$, JANA KRAUSE ${ }^{1}$, TE LIU ${ }^{1}$, JUAN \\ HÖFER $^{3}$, PABLO LODEIRO ${ }^{4}$, ERIC P. ACHTERBERG ${ }^{1}$, \\ THOMAS JUUL-PEDERSEN ${ }^{5}$ AND LORENZ MEIRE ${ }^{5}$ \\ ${ }^{1}$ GEOMAR Helmholtz Centre for Ocean Research Kiel \\ ${ }^{2}$ Department of Geochemistry, Geological Survey of Denmark \\ and Greenland \\ ${ }^{3}$ Pontificia Universidad Católica de Valparaíso \\ ${ }^{4}$ University of Lleida \\ ${ }^{5}$ Greenland Climate Research Centre \\ Presenting Author: mhopwood@geomar.de
}

Trace metals are essential micronutrients for life. Around the coastlines of Greenland and Antarctica sediment plumes associated with glacier runoff are a significant source of lithogenic material into the ocean, including large quantities of metals associated with particles. Yet the processes that moderate the exchange of trace elements between these particles and dissolved phases, which are generally more mobile and bioaccessible in the marine environment, are poorly understood. In order to gain insight into these processes, here we combine analysis of dissolved trace elements across the summertime salinity gradient in 8 case studies, with X-ray absorption spectroscopy of suspended particles from 3 glacier fjords with contrasting geology.

Across all study sites, general trends were evident in the behavior of different trace elements, with several elements including dissolved $\mathrm{Fe}$ and $\mathrm{Mn}$ always showing intense, yet rapidly attenuated, runoff associated sources. Suspended particle $\mathrm{Fe}$ speciation was relatively stable along fjords, with a consistently high fraction (typically $80-90 \%$ ) of Fe present as $\mathrm{Fe}(\mathrm{II})$-biotite in fjords derived from Precambrian shield geology and poorly-ordered $\mathrm{Fe}(\mathrm{III})$ phases dominant in one fjord with tertiary basalt. A decoupling of dissolved and particulate $\mathrm{Fe}$ was widespread. Repeat sections of selected glacier fjords on seasonal and inter-annual timescales suggested relatively strong buffering of some elements, exemplified by $\mathrm{Fe}$, which was typically present at a relatively constant dissolved concentration of $\sim 5 \mathrm{nM}$ in surface glacially modified waters despite strong gradients in turbidity. A GEOTRACES case study at Nioghalvfjerdsbrae, 'the $79^{\circ}$ North Glacier', was particularly insightful, as there contrasting $\mathrm{Mn}, \mathrm{Co}, \mathrm{Ni}, \mathrm{Cu}$ and $\mathrm{Zn}$ signatures were observed comparing a modest surface plume derived from recent runoff with a larger and more turbid subsurface plume emerging from the cavity beneath the floating ice tongue.

Finally, we test the biological significance of glacier derived particle phases by contrasting the biological response to particles with filtered meltwater and (micro)nutrient spikes demonstrating that particles may have a distinct fertilizing effect on phytoplankton even under trace metal replete conditions, likely due to factors beyond trace metal availability. 